January 2006

\title{
Living with globalization: a menace or a chance?
}

Fauziah Rabbani

Aga Khan University, fauziah.rabbani@aku.edu

Babar T Shaikh

Aga Khan University

Sarah Wamala

National Institute of Public Health, Sweden

Follow this and additional works at: https://ecommons.aku.edu/pakistan_fhs_mc_chs_chs Part of the Public Health Commons

\section{Recommended Citation}

Rabbani, F., Shaikh, B., Wamala, S. (2006). Living with globalization: a menace or a chance?. Journal of Pakistan Medical Association, 56(4), 195-196.

Available at: https://ecommons.aku.edu/pakistan_fhs_mc_chs_chs/306 


\section{Letter to the Editor}

\section{Living with globalization: a menace or a chance?}

'Globalization' refers to the increasing integration of economies around the world, the movement of people (labor) and knowledge (technology) across international borders. ${ }^{1}$ Along with undeniable world economic development, inequalities within and between nations, rising unemployment and sluggish social progress in countries not being able to cope with the pace of globalization, is of great concern. ${ }^{2}$ Where some of the world population segments have made tremendous progress, there is a fear that globalization is exacerbating poverty and jeopardizing health status of the vulnerable segments in developing countries. ${ }^{3}$ Tremendous benefits conferred to almost 5 billion people through superior technologies and knowledge, highlight the concomitant challenge of bringing the same to 1 billion people of sub-Saharan Africa and South Asia who are yet to benefit. Standards of living have improved. Infant mortality rates declined globally during 1970-1997, from 107 to 56 per thousand and life expectancy has risen from 55 years to 67 years. ${ }^{3}$ Judged by their Human Development Indicators (HDIs), today's poor countries are well ahead of where the leading countries

Table. Population, poverty and under 5 mortality trends in developing regions.

\begin{tabular}{lcccc}
\hline Regions & $\begin{array}{l}\text { Population } \\
\text { in millions }\end{array}$ & $\begin{array}{l}\text { Percentage } \\
\text { of population } \\
\text { <1\$/day } \\
\text { poverty line }\end{array}$ & $\begin{array}{l}\text { Under 5 } \\
\text { mortality in } \\
\text { children } \\
\text { below } \\
\text { poverty line }\end{array}$ & $\begin{array}{l}\text { Under 5 } \\
\text { mortality in } \\
\text { children } \\
\text { above } \\
\text { poverty line }\end{array}$ \\
\hline $\begin{array}{l}\text { Latin America } \\
\text { and the Caribbean }\end{array}$ & 293.4 & 10.6 & 98.2 & 52.3 \\
$\begin{array}{l}\text { Middle East and } \\
\text { North Africa }\end{array}$ & 119.8 & 4.3 & 145.1 & 78.8 \\
$\begin{array}{l}\text { South and South } \\
\text { East Asia }\end{array}$ & 1737.8 & 28 & 127.1 & 78.3 \\
$\begin{array}{l}\text { Sub-Saharan } \\
\text { Africa }\end{array}$ & 494.5 & 41.1 & 204.3 & 144.2 \\
\hline Total or average & $\mathbf{2 6 4 5 . 5}$ & $\mathbf{2 7 . 4}$ & $\mathbf{1 5 6 . 1}$ & $\mathbf{8 8 . 6}$ \\
\hline
\end{tabular}


countries were in 1870.4 This is largely because medical advances and improved living standards. Yet the quality of life for many has not improved, with many still living in abject poverty and moribund health systems, thus hampering access to essential drugs that could alleviate suffering or even prevent deaths. ${ }^{3}$

Merging borders may pose new challenges to global health, social fabrics and cultural identities. The risks and adverse consequences of globalization must be confronted, but they must not be allowed to obscure its overall positive impact on health and development. Low-income countries have not been able to integrate with the global economy as quickly as others, partly because of their chosen policies and partly because of factors outside their control. Does globalization really exacerbate health inequities? How can the developing countries be helped to catch up? Are countries that integrate with the global economy inevitably, become vulnerable to an overall instability? In this scenario, the key international organizations and alliances ought to facilitate the developing countries in all possible ways to combat with the diseases prevailing in these regions. Investing in health is imperative and the individual countries, donors and all other international players have to have this realization that this is the only way to development and boosting the economies and thus reducing poverty, the prime determinant of health. ${ }^{5}$ That is the only way to ensure all people in all countries have access to the benefits of globalization.

\section{References}

1. Baris E, McLeod K. Globalization and international trade in the twenty-first century. Opportunities for and threats to the health sector in the South. Intern J Health Services 2000, 30:187-210.

2. Dollar D. Is globalization good for your health? Bull World Health Org 2001, $79: 827-833$

3. World Bank. Poverty in an age of globalization. Geneva: 2000.

4. United Nations Development Programme. Human Development Report 2004. Cultural liberty in today's diverse world. New York: 2004.

5. Brundtland GH. Public health challenges in a globalizing world. Eur J Public Health 2005, 15(1): 3-5.

Fauziah Rabbani ${ }^{1}$, Babar T. Shaikh ${ }^{1}$, Sarah Wamala $^{2}$

Department of Community Health Sciences, Aga Khan University, Karachi. ${ }^{1}$ and Social Epidemiology Unit, National Institute of Public Health, Stockholm, Sweden. ${ }^{2}$ 